Gut, 1971, 12, 276-283

\title{
Dipeptidase deficiency and malabsorption of glycylglycine in disease states ${ }^{1}$
}

\author{
F. SADIKALI
}

From the Gordon and Westminster Hospitals, London

SUMMARY The activities of jejunal mucosal peptide hydrolases for glycylglycine, glycyl-L-leucine and L-leucylglycine, were assayed in 37 patients. Eight patients, four of whom had Crohn's disease, were found to have a marked reduction in the activity of glycylglycine dipeptidase and, to a lesser extent, of the other two hydrolases. Although absorption of glycine in the two groups was similar, there was malabsorption of glycylglycine in the patients with reduced dipeptidases as shown by a flat absorption curve. The importance of peptide hydrolases of small-intestinal mucosa in the final digestion of proteins, and the implications of peptidase deficiency in disease states is discussed. It is concluded that significant peptidase deficiency may occur even when the mucosa is otherwise histologically completely normal, similar to some states of disaccharidase deficiency described in recent years.

It is now generally agreed that in the adult, dietary protein enters the blood stream in nutritionally important quantities as amino acids (Levenson, Rosen, and Upjohn, 1959; Dawson and Holdsworth, 1962; Smyth, 1964). The peptide hydrolases of the small-intestinal mucosa are of considerable interest because it is becoming increasingly clear that they play an important part in the terminal phases of protein digestion (Newey and Smyth, 1960; Crane, 1961; Rhodes, Eichholz, and Crane, 1967). The small-intestinal mucosal cells are known to be rich in dipeptidases, and recently it has been shown by two different groups of workers that at least a portion of the intracellular peptide hydrolase activity for several different substrates is localized in the microvillous membranes (Friedrich, Noack, and Schlenk, 1965; Rhodes et al, 1967; Eichholz, 1968). The brush border membrane thus appears to have a hydrolytic mechanism to complete peptide digestion which is analogous to that of disaccharidases, which are similarly placed (Miller and Crane, 1961; Johnson, 1967). This has raised the possibility of states of peptidase deficiency, primary or secondary to disease states, similar to disaccharide intolerance and malabsorption.

Preliminary evidence has also been brought forward (Pittman and Pollitt, 1966; Kowlessar, 1967), to support the suggestion that gluten-induced

\footnotetext{
${ }^{2}$ Address reprint requests to: Department of Medicine, Makerere University, Kampala, Uganda.

Received for publication 9 December 1970.
}

enteropathy may perhaps be due to lack of a specific peptidase in the small-intestinal mucosa (Frazer, 1962). Despite increasing interest in the problem in the last few years, there are only a few reports in the literature of quantitative studies of dipeptidases of the small-intestinal mucosa in man under normal and pathological conditions (Messer, Anderson, and Townley, 1961; Lindberg, 1966a; Josefsson and Lindberg, 1967; Lindberg, Nordén, and Josefsson, 1968; Heizer and Laster, 1969; Douglas and Peters, 1970). No published data are available to confirm the significance of a dipeptidase deficiency by correlating the enzyme level with a 'tolerance' curve for the particular dipeptide. Results are reported in this paper of the assay of hydrolase activity for glycylglycine, glycyl-L-leucine and L-leucylglycine in peroral jejunal biopsies from a group of patients with and without gastrointestinal symptoms. The role and significance of deficiency of glycylglycine dipeptidase, thought to be a highly specific enzyme (Smith, 1951), in the absorption of glycylglycine was tested by comparing the tolerance curves for diglycine and glycine in those patients with depressed activity, against those with enzyme levels within the normal range.

\section{Materials and Methods}

Peroral biopsies were obtained from the first loop of the jejunum in all patients using the Carey capsule (Carey, 1964) which is a multi-biopsy 
instrument. On many occasions two specimens were available for study. Part of each specimen was examined under the dissecting microscope and also histologically. The specimen for enzyme estimation was quickly washed with normal saline, blotted dry, and weighed. The biopsy was homogenized in cold distilled water with a glass homogenizer; the concentration of tissue in the homogenate $(w / v)$ of water was generally 1 in 40 . Assay for dipeptidases was carried out on the same day in all except a few cases, as it has previously been found that the activity of such crude homogenates is labile and markedly diminishes when stored below $0^{\circ} \mathrm{C}$ (Robinson and Shaw, 1960). In those few instances where estimation for some reason could not be carried out on the same day, the specimen was stored as such below $-20^{\circ} \mathrm{C}$, and assay was done the next day or at least within three days. It has been shown that the activities are stable for up to three months under these conditions (Lindberg, 1966a).

\section{ASSAY OF DIPEPTIDASE ACTIVITY}

The reagents and conditions in the reaction mixture were based on the method described by Josefsson and Lindberg (1965), but the increase in ninhydrin colour (Matthews, Muir, and Baron, 1964) was used for estimating the degree of hydrolysis of the dipeptides. To assay the glycyl-L-leucine and L-leucylglycine dipeptidase activity, $200 \mu$ l of $0.0234 \mathrm{M}$ solution of chromatographically pure dipeptide was added to $200 \mu \mathrm{l}$ of $0 \cdot 18 \mathrm{M}$ borate buffer solution $\left(\mathrm{Na}_{2} \mathrm{~B}_{4} \mathrm{O}_{7} \cdot \mathrm{H}_{2} \mathrm{O}, p \mathrm{H} 7 \cdot 9\right)$ and incubated at $40^{\circ} \mathrm{C}$. At zero time $50 \mu \mathrm{l}$ of the crude homogenate (concentration: 1 in 80 for glycyl-L-leucine and 1 in 40 for L-leucylglycine) was added, and $25 \mu \mathrm{l}$ samples of the reaction mixture were withdrawn at $0,5,10$, and 15 minute intervals. Further hydrolysis was interrupted by immediately pipetting the samples into previously prepared test tubes containing a mixture of $0.5 \mathrm{ml}$ cyanide-acetate buffer and 0.5 $\mathrm{ml}$ of ninhydrin reagent, according to the method of Matthews et al (1964), which was used to estimate the increase in colour yield.

For the assay of glycylglycine dipeptidase $100 \mu \mathrm{l}$ of $0.0495 \mathrm{M}$ solution of diglycine was added to $100 \mu \mathrm{l}$ of the borate buffer, to which cobalt chloride had been added to give a final concentration of $8 \times 10^{-5} \mathrm{M}$ $\mathrm{Co}^{++}$in the reaction mixture. Twenty-five $\mu \mathrm{l}$ of the stock homogenate (concentration 1 in 40) was added at zero time, and $10 \mu \mathrm{l}$ samples were withdrawn at $0,15,30,45$, and 60 minutes, and pipetted into cyanide acetate buffer-ninhydrin mixture as above. A standard curve was constructed for each dipeptide with a mixture of various concentrations of the dipeptide and appropriate amounts of amino acids. Activity of each enzyme as shown by the increase in colour yield was plotted graphically against time, and by reference of the mean percentage of hydrolysis to the standard curve, enzyme activity was determined in units/mg wet weight of mucosa, one unit being defined as the enzyme activity hydrolyzing one $\mu \mathrm{mol}$ of dipeptide per hour at $40^{\circ} \mathrm{C}$.

DIGLYCINE AND GLYCINE TOLERANCE TESTS These were carried out as described by Craft, Geddes, Hyde, and Matthews (1969) but blood samples were taken for only 90 minutes after the oral dose. Plasma alpha-amino nitrogen was estimated by the method of Matthews et al (1964).

\section{Results}

RESULTS OF DIPEPTIDASE ASSAY

The reaction kinetics for the three dipeptidases were found to be similar to those reported by Robinson and Shaw (1960) with homogenates of rat small intestinal mucosa. Table I shows the results in a group of eight patients with no symptoms referable to the gastrointestinal tract but in whom intestinal biopsy had been carried out for further investigation of $\mathbf{B}_{12}$ or folate deficiency, unexplained weight loss, or iron-deficiency anaemia. The results

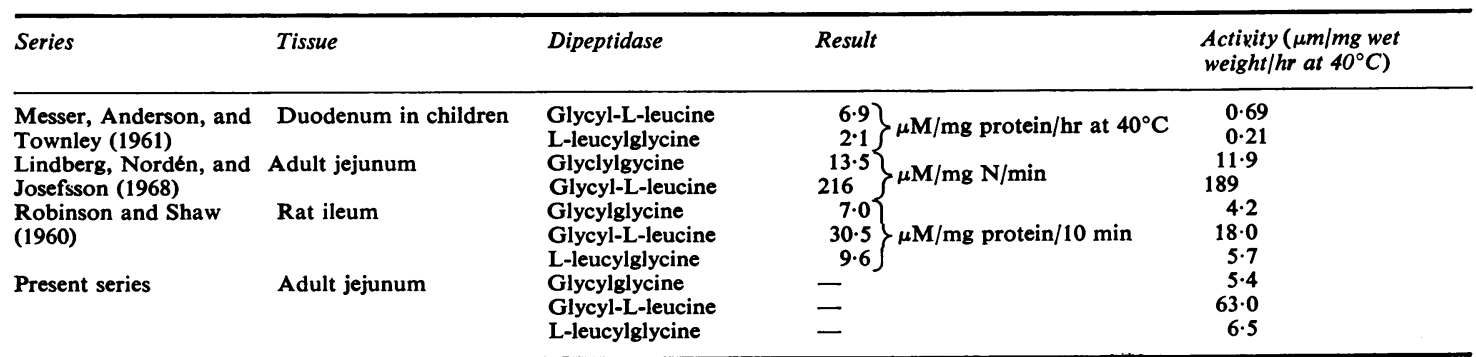

Table I Activities of hydrolase for glycylglycine, glycyl-L-leucine, and L-leucylglycine reported in different series 
in the present study are compared with those reported by other authors. Intestinal mucosa contains other nitrogenous substances besides protein, but for conversion it was assumed that 1 $\mathrm{mg}$ of nitrogen is equal to $6.25 \mathrm{mg}$ of protein, and that the latter forms $10 \%$ of wet weight of the biopsy tissue. These assumptions were made to obtain the same order of results, so that a rough comparison could be made between the activities of the enzymes reported in this and in previous series.

The only report of quantitative estimation of L-leucylglycine dipeptidase activity in human intestinal mucosa is that of Messer et al (1961) from duodenal biopsies in children, apart from the demonstration of activity for this dipeptide by Berger and Johnson (1940). The results reported in these former series are only a fraction of those found in the present study, but this is due to difference in technique as they used the whole biopsy and not homogenates for assay. For example Newey and Smyth (1960) found that the dipeptidase activity of homogenates of the mucosa was very much greater than the intact absorbing surface. Both the actual results, and the ratio of the various activities to each other are of similar order to the findings in rat ileum reported by Robinson and Shaw (1960). Lindberg et al (1968) assayed the hydrolases for glycylglycine, glycyl-L-leucine, and for several other dipeptides, in biopsies from 22 patients with gastrointestinal disorders. The results for the two enzymes in this series are much higher, but this is only apparent, because the crude homogenate containing an unknown amount of protein was centrifuged, and enzyme was estimated in, and related to the amount of nitrogen in the clear supernatant (Josefsson and Lindberg, 1965).

Assay of the three dipeptidase requires $100 \mu \mathrm{l}$ of the stock homogenate, or a minimum of about 5 $\mathrm{mg}$ of tissue, and as 15 to $40 \mathrm{mg}$ was available on each occasion, repeat estimation could be carried out when required, and several other enzymes, including the dissaccharidases, could be estimated at the same time. It is clear from Table $I$ that the results obtained by this method are comparable to those reported previously in the small-intestine both in man and the rat.

The results in the first group are contrasted in Table II with those in 12 patients (group II) who were investigated for diarrhoea, with or without abdominal pain, and found to be examples of the 'irritable colon' syndrome. Enzyme activities in the two groups were similar, except one patient (case 5) who had reduced level of glycylglycine activity, and who is also included in group IV, which consisted of eight subjects with dipeptidase 'deficiency'. There were nine patients with Crohn's disease, four of whom showed markedly depressed levels of the three dipeptidases, while the activities were within the normal range in the remaining five subjects. All had an acute relapse of symptoms, six had been referred for the first time for investigation; and the diagnosis was made and confirmed at this admission. Dissecting microscopy showed minor abnormalities in the biopsy from one of these four patients with reduced dipeptidases, although histology was normal. Similar morphological abnormality was also found in another patient with Crohn's disease and normal enzyme levels; whilst in a third patient, also with normal enzyme activities, the specimen appeared normal under the dissecting microscope but showed oedema and inflammatory cell infiltration histologically.

The series included five patients with steatorrhoea, two of them with glutein-induced enteropathy, and two with pancreatic insufficiency. The latter four were found to have activities within the range of those in groups I and II, and are included with the five patients with Crohn's disease who had normal enzyme levels as group III (Table III). The patient with steatorrhoea who had markedly reduced dipeptidases was found to have a normal intestinal biopsy and steatorrhoea of unknown origin. Some of the clinical details, and results of tests for malabsorption in groups III and IV are shown in Tables III and IV. It is seen that amongst the eight patients

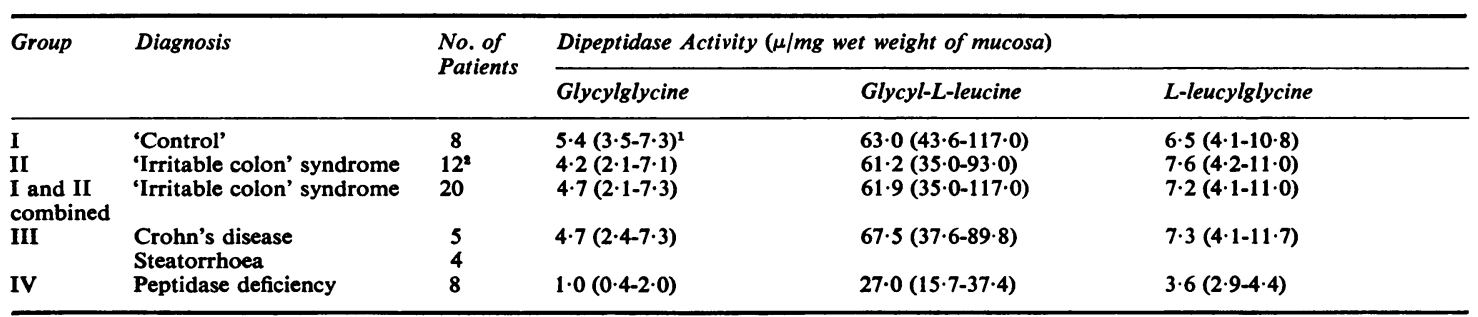

Table II Dipeptidases in different groups of patients.

${ }^{1}$ Mean; range given in parentheses.

${ }^{2}$ Contains one patient from group II also in group IV. 


\begin{tabular}{|c|c|c|c|c|c|c|c|c|c|}
\hline \multirow[t]{2}{*}{ Case No. } & \multirow[t]{2}{*}{ Diagnosis } & \multirow[t]{2}{*}{ Age } & \multirow[t]{2}{*}{ Sex } & \multirow[t]{2}{*}{$\begin{array}{l}\text { Faecal Fat } \\
(g / 24 \mathrm{hr})\end{array}$} & \multirow{2}{*}{$\begin{array}{l}\text { Five-hour } \\
\text { D-xylose } \\
\text { Excretion } \\
\text { after } 5 g \\
\text { Dose }\end{array}$} & \multirow[t]{2}{*}{$\begin{array}{l}\text { Histology of } \\
\text { Jejunal Biopsy }\end{array}$} & \multicolumn{3}{|c|}{$\begin{array}{l}\text { Dipeptidase Activity }(\mu / m g \\
\text { wet weight) }\end{array}$} \\
\hline & & & & & & & Glyglycine & $\begin{array}{l}\text { Gly-L- } \\
\text { leucine }\end{array}$ & $\begin{array}{l}\text { L-leugly- } \\
\text { cine }\end{array}$ \\
\hline 6 & $\begin{array}{l}\text { Crohn's disease } \\
\text { Terminal ileum and colon }\end{array}$ & 28 & $\mathbf{F}$ & $2 \cdot 0$ & - & Normal & $5 \cdot 2$ & $75 \cdot 6$ & $8 \cdot 7$ \\
\hline 18 & $\begin{array}{l}\text { Crohn's disease } \\
\text { Terminal ileum and colon }\end{array}$ & 21 & $\mathbf{F}$ & - & $1 \cdot 46$ & Normal & $4 \cdot 5$ & $37 \cdot 6$ & $8 \cdot 0$ \\
\hline 24 & $\begin{array}{l}\text { Crohn's disease } \\
\text { Terminal ileum and colon }\end{array}$ & 18 & $\mathbf{M}$ & $4 \cdot 0$ & - & Normal & $2 \cdot 4$ & $42 \cdot 5$ & $4 \cdot 7$ \\
\hline 30 & $\begin{array}{l}\text { Crohn's disease } \\
\text { Terminal ileum and colon }\end{array}$ & 27 & $\mathbf{M}$ & $2 \cdot 0$ & 1.6 & $\begin{array}{l}\text { Normal villi but } \\
\text { marked oedema and } \\
\text { inflammatory cell } \\
\text { infiltration of mucosa }\end{array}$ & $4 \cdot 5$ & $51 \cdot 2$ & $11 \cdot 7$ \\
\hline 33 & $\begin{array}{l}\text { Crohn's disease } \\
\text { Terminal ileum }\end{array}$ & 22 & $\mathbf{M}$ & $4 \cdot 0$ & - & $\begin{array}{l}\text { Mixed pattern of } \\
\text { leaves and convolutions; } \\
\text { normal histology }\end{array}$ & ${ }^{7 \cdot 3}$ & 86.0 & $6 \cdot 3$ \\
\hline 34 & $\begin{array}{l}\text { Glutein-induced } \\
\text { steatorrhoea }\end{array}$ & 47 & $\mathbf{M}$ & 0.45 & 0.45 & $\begin{array}{l}\text { Subtotal villous } \\
\text { atrophy }\end{array}$ & $5 \cdot 3$ & $89 \cdot 8$ & $9 \cdot 2$ \\
\hline $\begin{array}{l}14 \\
17\end{array}$ & $\begin{array}{l}\text { Pancreatic steatorrhoea } \\
\text { Pancreatic steatorrhoea }\end{array}$ & $\begin{array}{l}32 \\
21\end{array}$ & $\begin{array}{l}\mathbf{M} \\
\mathbf{F}\end{array}$ & $\begin{array}{l}32 \cdot 0 \\
43 \cdot 0\end{array}$ & $\begin{array}{l}0.99 \\
1.55\end{array}$ & $\begin{array}{l}\text { Normal } \\
\text { Normal }\end{array}$ & $\begin{array}{l}4 \cdot 2 \\
5 \cdot 7\end{array}$ & $\begin{array}{l}87 \cdot 0 \\
93 \cdot 0\end{array}$ & $\begin{array}{l}4 \cdot 1 \\
5 \cdot 8\end{array}$ \\
\hline $\begin{array}{l}\text { Mean } \\
\text { activity }\end{array}$ & & & & & & & $4 \cdot 7$ & $67 \cdot 5$ & $7 \cdot 3$ \\
\hline
\end{tabular}

Table III Patients with normal peptidases (group III)

\begin{tabular}{|c|c|c|c|c|c|c|c|c|c|}
\hline \multirow[t]{2}{*}{ Case No. } & \multirow[t]{2}{*}{ Diagnosis } & \multirow[t]{2}{*}{ Age } & \multirow[t]{2}{*}{ Sex } & \multirow[t]{2}{*}{$\begin{array}{l}\text { Faecal Fat } \\
(g / 24 \mathrm{hr})\end{array}$} & \multirow{2}{*}{$\begin{array}{l}\text { Five-hour } \\
\text { D-xylose } \\
\text { Excretion } \\
\text { after } 5 g \\
\text { Dose }\end{array}$} & \multirow[t]{2}{*}{$\begin{array}{l}\text { Histology of } \\
\text { Jejunal Biopsy }\end{array}$} & \multicolumn{3}{|c|}{$\begin{array}{l}\text { Dipeptidase Activity ( } \mu / m g \\
\text { wet weight) }\end{array}$} \\
\hline & & & & & & & Glyglycine & $\begin{array}{l}\text { Gly-L- } \\
\text { leucine }\end{array}$ & $\begin{array}{l}\text { L-leugly- } \\
\text { cine }\end{array}$ \\
\hline 1 & $\begin{array}{l}\text { Severe diarrhoea; } \\
\text { duodenal diverticulum }\end{array}$ & 69 & $\mathbf{M}$ & $3 \cdot 0$ & $1 \cdot 6$ & Normal & 0.74 & $37 \cdot 4$ & 3.9 \\
\hline 3 & $\begin{array}{l}\text { Idiopathic } \\
\text { steatorrhoea }\end{array}$ & 55 & $\mathbf{F}$ & $30 \cdot 3$ & 0.62 & Normal & 0.64 & $22 \cdot 4$ & $3 \cdot 2$ \\
\hline 4 & Hartnup disease & 25 & $\mathbf{F}$ & - & - & Normal & $2 \cdot 0$ & $16 \cdot 6$ & 2.9 \\
\hline 5 & $\begin{array}{l}\text { 'Irritable colon' } \\
\text { syndrome }\end{array}$ & 20 & $\mathbf{M}$ & $4 \cdot 0$ & 0.96 & Normal & $1 \cdot 34$ & $35 \cdot 8$ & $4 \cdot 2$ \\
\hline 21 & $\begin{array}{l}\text { Crohn's disease } \\
\text { term ileum and colon }\end{array}$ & 19 & $\mathbf{F}$ & $4 \cdot 0$ & 1.95 & Normal & 1.95 & $36 \cdot 7$ & $4 \cdot 4$ \\
\hline 25 & $\begin{array}{l}\text { Crohn's disease } \\
\text { lower ileum and colon }\end{array}$ & 44 & $\mathbf{M}$ & 5.0 & $0 \cdot 78$ & $\begin{array}{l}\text { Some leaves; } \\
\text { normal histology }\end{array}$ & 0.56 & $29 \cdot 2$ & $3 \cdot 3$ \\
\hline 26 & $\begin{array}{l}\text { Crohn's disease } \\
\text { jejunum and ileum }\end{array}$ & 18 & $\mathbf{M}$ & - & - & Normal & 0.74 & $22 \cdot 4$ & $3 \cdot 1$ \\
\hline 28 & $\begin{array}{l}\text { Crohn's disease } \\
\text { jejunum and ileum }\end{array}$ & 19 & $\mathbf{M}$ & $8 \cdot 9$ & 1.45 & Normal & 0.41 & $15 \cdot 7$ & $4 \cdot 1$ \\
\hline $\begin{array}{l}\text { Mean } \\
\text { activity } \\
\text { Range }\end{array}$ & & & & & & & $\begin{array}{l}1.0 \\
0.41-1.95\end{array}$ & $\begin{array}{l}27 \cdot 0 \\
15 \cdot 7-37 \cdot 4\end{array}$ & $\begin{array}{l}3 \cdot 6 \\
2 \cdot 9-4 \cdot 4\end{array}$ \\
\hline
\end{tabular}

Table IV Data on patients with peptidase deficiency (group IV)

with peptidase deficiency, only one had steatorrhoea, whilst another subject had normal stool fat excretion, but was found to have abnormal D-xylose absorption.

\section{RESULTS OF GLYCINE AND DIGLYCINE TOLERANCE TESTS}

These results are shown in Tables V and VI. Seven of the patients with glycylglycine dipeptidase within the normal range had both tests, and in one subject the glycine test was omitted as diglycine absorption was found to be normal. Six of the eight subjects with 'peptidase deficiency' in group IV had both tolerance tests. The kinetics of these tests have been previously fully described by Craft et al (1969), and in accordance with their findings it was found that the increase in plasma alpha amino nitrogen at 30 minutes was significantly higher (3.94 $\mathrm{mg} \%$ compared to $2.43 \mathrm{mg} \%, \quad$ P $<0.02$ ) after diglycine than following glycine in the seven patients with normal glycylglycine dipeptidase activity. The most striking finding was a subnormal rise in plasma alpha amino nitrogen after diglycine in all the six patients from group IV. The mean 


\begin{tabular}{|c|c|c|c|c|c|c|c|c|c|c|c|c|c|c|}
\hline \multirow{3}{*}{$\begin{array}{l}\text { Case } \\
\text { No. }\end{array}$} & \multicolumn{7}{|c|}{ Diglycine Test } & \multicolumn{7}{|c|}{ Glycine Test } \\
\hline & \multirow{2}{*}{$\begin{array}{l}\text { Fasting } \\
\text { Plasma } \\
\text { a- } \mathrm{NH}_{\mathbf{g}} \mathrm{N} \\
(\mathrm{mg} \%)\end{array}$} & \multicolumn{5}{|c|}{ Rise in Plasma a-NH$H_{2} \mathrm{~N}(m \mathrm{~g} \%)$} & \multirow{2}{*}{ Peak Rise } & \multirow{2}{*}{$\begin{array}{l}\text { Fasting } \\
\text { Plasma } \\
a-\mathrm{NH}_{\mathbf{2}} \mathrm{N} \\
(\mathrm{mg} \%)\end{array}$} & \multicolumn{5}{|c|}{ Rise in Plasma a-NH $\mathrm{N}_{2} \mathrm{~N}(\mathrm{mg} \%)$} & \multirow[t]{2}{*}{ Peak Rise } \\
\hline & & $15 \mathrm{~min}$ & $30 \mathrm{~min}$ & $45 \mathrm{~min}$ & $60 \mathrm{~min}$ & $90 \mathrm{~min}$ & & & $15 \mathrm{~min}$ & $30 \mathrm{~min}$ & $45 \mathrm{~min}$ & $60 \mathrm{~min}$ & $90 \min$ & \\
\hline $\begin{array}{r}2 \\
13 \\
19 \\
29 \\
30 \\
31 \\
34 \\
35\end{array}$ & $\begin{array}{l}4 \cdot 7 \\
3.6 \\
4.8 \\
3.4 \\
3.9 \\
3.3 \\
3.5 \\
3.9\end{array}$ & $\begin{array}{l}1.2 \\
1.7 \\
0.6 \\
1.2 \\
1.8 \\
3.3 \\
0.1 \\
1.7\end{array}$ & $\begin{array}{l}4 \cdot 0 \\
3.8 \\
6.0 \\
3.4 \\
4 \cdot 7 \\
4 \cdot 6 \\
2.4 \\
2 \cdot 6\end{array}$ & $\begin{array}{l}4 \cdot 3 \\
3 \cdot 5 \\
3.9 \\
3 \cdot 4 \\
3.9 \\
5 \cdot 1 \\
3 \cdot 6 \\
3 \cdot 5\end{array}$ & $\begin{array}{l}4 \cdot 2 \\
3 \cdot 1 \\
2 \cdot 7 \\
3 \cdot 7 \\
2 \cdot 6 \\
4 \cdot 1 \\
3 \cdot 1 \\
2.5\end{array}$ & $\begin{array}{l}1 \cdot 3 \\
2 \cdot 4 \\
1 \cdot 3 \\
2.9 \\
0 \cdot 8 \\
2 \cdot 4 \\
1 \cdot 5 \\
0.9\end{array}$ & $\begin{array}{l}4 \cdot 3 \\
3 \cdot 8 \\
6 \cdot 0 \\
3 \cdot 7 \\
4 \cdot 7 \\
5 \cdot 1 \\
3 \cdot 6 \\
3 \cdot 5\end{array}$ & $\begin{array}{l}4 \cdot 1 \\
3.8 \\
3 \cdot 7 \\
3.5 \\
3.7 \\
\overrightarrow{3.5} \\
4.0\end{array}$ & $\begin{array}{l}1 \cdot 3 \\
0.5 \\
1 \cdot 3 \\
1.5 \\
2 \cdot 2 \\
\frac{0.3}{0.2}\end{array}$ & $\begin{array}{l}2.3 \\
1.6 \\
3.1 \\
2.9 \\
3.8 \\
-1.7 \\
1.6\end{array}$ & $\begin{array}{l}3.9 \\
2.9 \\
3.3 \\
3.3 \\
2.5 \\
2.3 \\
2.4\end{array}$ & $\begin{array}{l}3.8 \\
2.8 \\
2.6 \\
3.0 \\
2.5 \\
2.0 \\
2.6\end{array}$ & $\begin{array}{l}3.5 \\
2.0 \\
1.2 \\
2.5 \\
1.0 \\
\overrightarrow{0.9} \\
1.7\end{array}$ & $\begin{array}{l}3.9 \\
2.9 \\
3 \cdot 3 \\
3 \cdot 3 \\
3 \cdot 8 \\
2.3 \\
2 \cdot 6\end{array}$ \\
\hline Mean & & & \multicolumn{4}{|c|}{$3.94 \pm 0.42$} & \multicolumn{3}{|l|}{$4.34 \pm 0.31$} & \multicolumn{4}{|c|}{$2.43 \pm 0.33$} & $3 \cdot 16 \pm 0 \cdot 22$ \\
\hline
\end{tabular}

Table $\mathrm{V}$ Rises in plasma $\alpha-N H^{2} N$ in patients with normal dipeptidases following diglycine and glycine

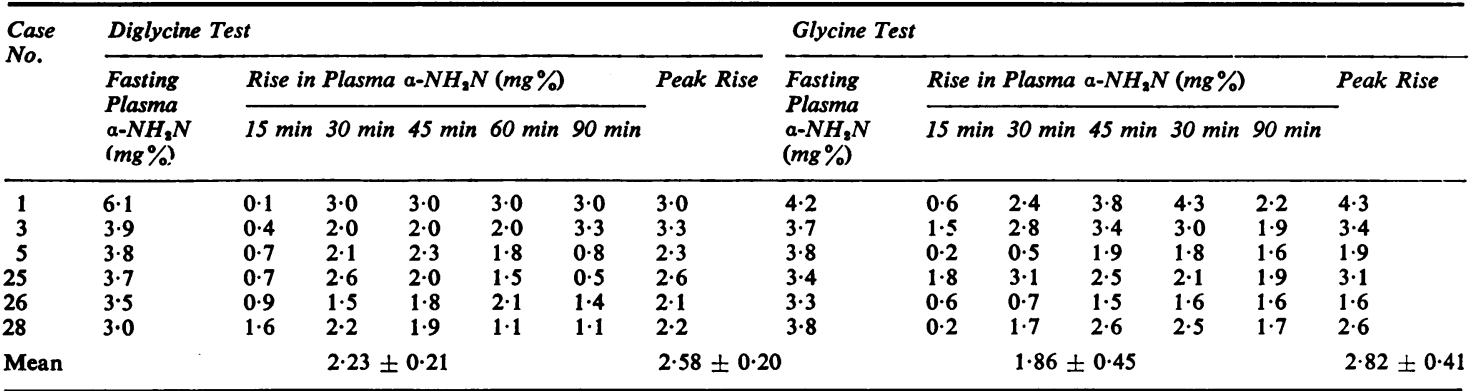

Table VI Rises in plasma $\alpha-N H^{2} N$ in patients with reduced dipeptidases following diglycine and glycine

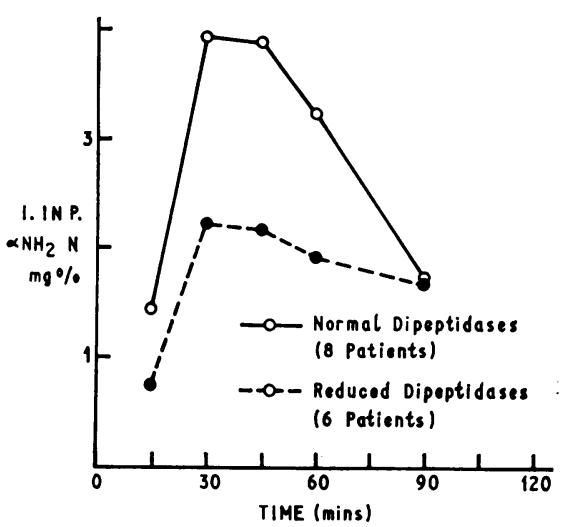

Fig. 1.

Diglycine tolerance curve in eight patients with peptidases within the normal range, compared to six patients with markedly reduced glycylglycine and the other two dipeptidases. (I. in $P .=$ increase in plasma.)

Fig. 2. Glycine tolerance curve in seven patients with normal peptidases compared to that in six patients with reduced dipeptidases. The glycylglycine curve in the latter six patients is also shown. Absorption curve for glycine in the two groups of patients is similar.

increase was only $2.23 \mathrm{mg} \%$ compared to $3.94 \mathrm{mg} \%$ in the other patients, whilst the mean of the maximum rise (regardless of the time) was $2.58 \mathrm{mg} \%$ and $4.34 \mathrm{mg} \%$ respectively, the difference in both sets of values being highly significant $(P<0.01)$.
Absorption of glycine in the two groups was similar (Tables V and VI), indicating that neither malabsorption of glycine as such, nor the specific effect of diarrhoea and intestinal hurry, was responsible for the flat curve with diglycine in this 
group of six patients. In fact it is apparent that it is the hydrolytic mechanism which is becoming the limiting factor, and causes the absorption curve for diglycine to become flat and depressed below that for glycine, as shown in Figures I and II. This is consistent with the reduced levels of glycylglycine dipeptidase in these patients. Taken for the group as a whole the level below which the dipeptidase 'deficiency' becomes an important limiting factor is about one unit.

\section{Discussion}

Evidence is accumulating of the important role of peptide hydrolases of the small intestinal mucosa in the final digestion of proteins. Newey and Smyth (1960) showed that the various dipeptides they tested were able to enter small intestinal cells without prior hydrolysis, and evidence was presented to show that hydrolysis of glycylglycine must occur intracellularly. The recent investigations of Craft et al (1969) in both man and rat (Matthews, Craft, Geddes, Wise, and Hyde, 1968) on the rates of absorption of glycine and its oligopeptides have supported this, and on the basis of their results Craft et al have postulated that glycine, and its dipeptide and tripeptide probably share a rate limiting step before hydrolysis. Further studies (Matthews, Lis, Cheng, and Crampton, 1969) on the rates of absorption of several oligopeptides of methionine and glycine, including mixed peptides, showed that these are also probably taken up intact from the intestinal lumen. These observations strongly support the idea that protein might be removed from the lumen largely in the form of peptides of two or three amino acids, and is consistent with the finding that after a protein meal the bulk of digestion products in the lumen are in this form (Chen, Rogers, and Harper, 1962). The various dipeptidases of intestinal mucosa have not been isolated separately, but the general opinion is that they have a high degree of specificity (Lindberg, 1966b). In particular Smith (1961) on the basis of detailed studies in various tissues, including intestinal mucosa, concluded that glycylglycine dipeptidase was a highly specific enzyme. The finding in the present study of a flat tolerance curve with diglycine in those patients with markedly reduced glycylglycine dipeptidase confirms the role of this enzyme in the intracellular hydrolysis during its absorption.

The other two dipeptidases were also diminished in most of these patients, although the reduction was proportionately much lower. The reason for the fall in dipeptidase activities is not certain from the present study; it may well be a nonspecific effect, similar to disaccharidase deficiency in states of protein malnutrition (Bowie, Brinkman, and Hansen, 1965; Stanfield, Hutt, and Tunnicliffe, 1965). Nitrogen balance studies have also shown that in this condition nitrogen absorption may be as low as $30 \%$ even on very low protein intake, and in the initial stages of recovery faecal losses of nitrogen may be large (Linder, Hansen, and Karabus, 1963). Neale (1968) has reviewed the causes of protein malnutrition due to gastrointestinal disease in the adult, and suggested the possibility of reduced intestinal as well as pancreatic proteolytic enzymes in states of protein malnutrition, causing inadequate digestion and absorption, which may often coexist with inadequate protein intake. In this connexion, the finding of depressed levels in four out of nine patients with Crohn's disease merits further investigation. Whatever the cause, peptidase deficiency and resulting peptide malabsorption may exacerbate the protein-losing enteropathy, rapid wasting and weight loss, and low serum albumin levels so commonly found in patients acutely ill with this condition.

The biopsies were morphologically and histologically normal in all patients with peptidase deficiency, apart from the one patient with Crohn's disease where the biopsy showed minor morphological abnormalities under the dissecting microscope but was histologically normal. The finding of depressed activities in one patient with 'irritable colon' syndrome, and another with severe diarrhoea from a large solitary duodenal diverticulum, were unexpected as all other tests for malabsorption were negative, but a similar observation in an adult patient with Hartnup disease in relapse is of great theoretical interest. Asatoor, Bandoh, Lant, Milne, and Navab (1969) have shown that in this patient, absorption of the dipeptide carnosine ( $\beta$-alanyl-Lhistidine), and $\beta$-alanine was normal but that of L-histidine, and L-phenylalanine was grossly reduced (Navab and Asatoor, 1970). The normal absorption of carnosine suggested that amino acid nutrition in Hartnup disease is maintained more by absorption of oligopeptides than by transport of free essential amino acids, and it may be speculated whether the relapse and clinical presentation for the first time in adult life in this patient was related to fall in peptidase activities observed.

Lindberg et al (1968) also reported reduced activities for some of the dipeptidases in three of their ten patients with normal intestinal biopsy and steatorrhoea of unknown origin not improving on glutenfree diet, a similar finding to that in the patient with idiopathic steatorrhoea (case 3 in Table IV) in the present series. In the presence of villous atrophy, both children (Lindberg, 1967) and adults (Lindberg et $a l, 1968$ ) with gluten-induced enteropathy 
showed significantly lower figures for all the dipeptidases assayed, although no reliable lack of any one enzyme was observed. Douglas and Peters (1970) also found significantly reduced hydrolase activities for glycylglycine and L-leucyl-L-leucine in patients with adult Coeliac disease, and the fall was concluded to be due to non-specific effect of mucosal damage. Recently Heizer and Laster (1970) have reported that biopsy specimens from patients with various intestinal disorders, but without flattened mucosa (although seven of the nine patients in whom these enzymes were assayed did show other abnormalities of the mucosa), and in three patients with flattened mucosa showed a disproportionate reduction in glycyl-L-proline and phenylalanine-L-proline hydrolase activities, with the reduction being more marked in the patients with villous atrophy. It was suggested that the imidopeptide hydrolases were sensitive to intestinal disease generally, particularly to the process associated with flattening of the mucosa.

It is difficult to assess the clinical significance of the findings in the present investigation and studies as above, in view of the great functional reserve in the small intestine in man for absorption of proteins (Borgström, Dahlquist, Lundh, and Sjövall, 1957), and the fact the dipeptidase activities in man reach towards maximum in the distal ileum (Lindberg, 1966a). However despite this it has been possible in this study to show that malabsorption of glycylglycine can be demonstrated in association with markedly reduced activity for its corresponding dipeptidase in the jejunal mucosa from patients with various gastrointestinal disorders and that significant deficiency of peptide hydrolases may occur even when the mucosa in such patients is otherwise completely normal histologically-similar to some states of disaccharidase deficiency described in recent years.

I would like to thank Dr R. D. Tonkin and Dr F. B. Gibberd for much helpful encouragement and permission to study patients under their care; Dr D. M. Matthews, Dr J. B. McGillivray, Miss M. Lis, and other staff of Vincent Square Laboratories of Westminster Hospital for their continuous help and cooperation with some of the estimations and for the histology; and the nursing staff of Gordon and Westminster Hospitals who assisted in this investigation.

\section{References}

Asatoor, A. M., Bandoh, J. K., Lant, A. F., Milne, M. D., and Navab, F. (1970). Intestinal absorption of carnosine and its constituent amino acids in man. Gut, 11, 250-254.
Berger, J., and Johnson, M. J. (1940). The occurrence of leucylpeptidase. J. biol. Chem., 133, 157-172.

Borgström, B., Dahlqvist, A., Lundh, G., and Sjövall, J. (1957) Studies of intestinal digestion and absorption in the human. J. clin. Invest., 36, 1521-1536.

Bowie, M. D., Brinkman, G. L., and Hansen, J. D. L. (1965). Acquired disaccharide intolerance in malnutrition. J. Pediat., 66, 1083-1091.

Carey, J. B., Jr. (1964). A simplified gastrointestinal biopsy capsule. Gastroenterology, 46, 550-557.

Chen, M. L., Rogers, Q. R., and Harper, A. E. (1962). Observations on protein digestion in vivo. IV. Further observations on gastrointestinal contents of rats fed different dietary proteins. J. Nutr., 76, 235-41.

Craft, I. L., Geddes, D., Hyde, C. W., Wise, I. J., and Matthews, D. M. (1969). Absorption and malabsorption of glycine and glycine peptides in man. Gut, 9, 425-437.

Crane, C. W. (1961). Some aspects of protein digestion and absorption in health and disease. Postgrad. med. J., 37, 745-754.

Dawson, R., and Holdsworth, E. S. (1962). An investigation into protein digestion with ${ }^{14} \mathrm{C}$-labelled protein. Brit. J. Nutr., 16, 13-38.

Douglas, A. P., and Peters, T. J. (1970). Peptide hydrolase activity of human intestinal mucosa in adult coeliac disease. Gut, 11, 15-17.

Eichholz, A. (1968). Studies on the organisation of the brush border in intestinal cells. V. Subfractionation of enzymatic activities of the microvillous membrane. Biochim. biophys. Acta (Amst.), 163, 101-107.

Frazer, A. C. (1962). The malabsorption syndrome, with special reference to the effects of wheat glutein. Advanc. clin. Chem., 5, 69-106.

Friedrich, M., Noack, R., and Schenk, G. (1965). Zur Lokalisation von peptidatischen und proteolytischen Aktivitäten in isolierten Bürstensäumen aus der Mucosa des Trattendünnclarmes. Biochem. Z., 343, 346-353.

Heizer, W. D., and Laster, L. (1969). Peptide hydrolase activities of the mucosa of human small intestine. J. clin. Invest., 48, 210-228.

Johnson, C. F. (1967). Disaccharidase: localisation in hamster intestinal brush borders. Science, 155, 1670-1672.

Josefsson, L., and Lindberg, T. (1965). Intestinal dipeptidases. I. Spectrophotometric determination and characterisation of dipeptidase activity in pig intestinal mucosa. Biochim. biophys. Acta (Amst.), 105, 149-161.

Josefsson, L., and Lindberg, T. (1967). Intestinal dipeptidases. IX. Studies on dipeptidases of human intestinal mucosa. Acta chem. scand., 21, 1965-1966.

Kowlessar, O. D. (1967). Effect of wheat proteins in celiac disease. Gastroenterology, 52, 893-897.

Levenson, S. M., Rosen, H., and Upjohn, H. L. (1959). Nature and appearance of protein digestion products in upper mesenteric blood. Proc. Soc. exp. Biol. (N.Y.), 101, 178-180.

Lindberg, T. (1966a). Intestinal dipeptidases. Dipeptidase activity in the mucosa of the gastrointestinal tract of the adult human. Acta physiol. scand., 66, 437-443.

Lindberg, T. (1966b). Studies on intestinal dipeptidases. Acta physiol. scand. V. 69, Suppl. 285.

Lindberg, T. (1967). Dipeptidase activity in small intestinal mucosa in patients with gluten-induced enteropathy. Acta paediat. scand., 56, Suppl. 177, 23-24.

Lindberg, T., Nordén, A., and Josefsson, L. (1968). Intestinal dipeptidases. Dipeptidase activities in small intestinal biopsy specimens from a clinical material. Scand. J. Gastroent., 3, 177-182.

Linder, G. C., Hansen, J. D. L., and Karabus, C. D. (1963). The metabolism of magnesium and other inorganic cations and of nitrogen in acute kwashiorkor. Pediatrics, 31, 552-568.

Matthews, D. M., Muir, G. G., and Baron, D. N. (1964). Estimation of alpha-amino nitrogen in plasma and urine by the colorimetric ninhydrin reaction. J. clin. Path., 17, 150-153.

Matthews, D. M., Craft, I. L., Geddes, D. M., Wise, I. J., and Hyde, C. W. (1968). Absorption of glycine and glycine peptides from the small intestine of the rat. Clin. Sci., 35, 415-424.

Matthews, D. M. Lis, M. T., Cheng, B., and Crampton, R. F. (1969). Observations on the intestinal absorption of some oligopeptides of methionine and glycine in rat. Clin. Sci., 37, 751-764. 
Messer, M., Anderson, C. M., and Townley, R. R. W. (1961). Peptidase activity of biopsies of the duodenal mucosa of children with and without coeliac disease. Clin. chim. Acta., 6, 768-775.

Miller, D., and Crane, R. K. (1961). The digestive function of the epithelium of the small intestine. II. Localization of disaccharide hydrolysis in the isolated brush border portion of intestinal epithelial cells. Biochim. biophys. Acta (Amst.), 52, 293-298.

Navab, F., and Asatoor, A. M. (1970). Studies on intestinal absorption of amino acids and a dipeptide in a case of Hartnup disease. Gut, 11, 373-379.

Neale, G. (1968). Protein malnutrition in gastro-intestinal disease. Postgrad. med. J., 44, 642-645.

Newey, H., and Smyth, D. H. (1960). Intracellular hydrolysis of dipeptides during intestinal absorption. J. Physiol. (Lond.), 152, 367-380.

Pittman, F. E., and Pollitt, R. J. (1966). Studies of jejunal mucosal digestion of peptic-tryptic digests of wheat protein in coeliac disease. Gut, 7, 368-371.

Rhodes, J. B., Eichholz, A., and Crane, R. K. (1967). Studies on the organisation of the brush border in intestinal epithelial cells. IV. Aminopeptidase activity in microvillous membranes of hamster intestinal brush borders.Biochim. biophys. Acta (Amst.), $135,959-965$.

Robinson, G. B., and Shaw, B. (1960). The hydrolysis of dipeptides by different regions of rat small intestine. Biochem. J., 77, 351-356.

Smith, E. L. (1951). The specificity of certain peptidases. Advanc. Enzymol., 12, 191-257.

Smyth, D. H. (1964). Mechanisms for amino-acid absorption. In The Role of the Gastrointestinal Tract in Protein Metabolism, edited by H. N. Munro, pp. 283-292. Blackwell, Oxford.

Stanfield, J. P., Hutt, M. S. R., and Tunnicliffe, R. (1965). Intestinal biopsy in kwashiorkor. Lancet, 2, 519-523. 